\title{
JUURNAL.RU
}

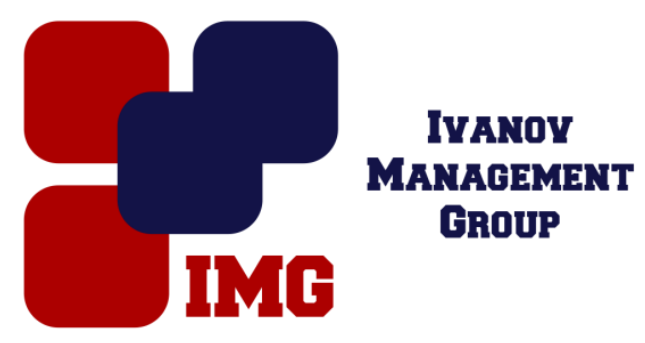

Филиппова Е.Н., Парфенов К.А. Мордовский государственный педагогический институт имени М. Е. Евсевьева Саранск, Россия

doi: $10.18411 / \mathrm{lj}-31-05-2017-30$

idsp 000001:1j-31-05-2017-30

\section{Методические особенности построения тренировочного процесса в биатлоне}

Биатлон, как вид спорта, непосредственно связан с проблемами тренировки в лыжных гонках и ведением стрельбы в сложных, часто меняющихся условиях, при дефиците времени и на фоне значительного утомления. Успешное выступление в соревнованиях во многом зависит от определения направленности, содержания и структуры тренировочного процесса, установления динамики основных показателей тренировочного процесса, что создает оптимальные условия для максимального проявления индивидуальных возможностей спортсмена[2].

Рост популярности биатлона выдвинул проблему разносторонней подготовки спортивных резервов, начиная с юношеского возраста. Стрелковая подготовка является одним из важнейших звеньев системе кругло годичной тренировке биатлонистов. За последние годы проведены многочисленные исследования, в которых научно обоснованы практические рекомендации по методике совершенствования стрелковой подготовки квалифицированных биатлонистов[4].

Анализ результатов выступления ведущих биатлонистов мира показывает, что в современном биатлоне отчетливо прослеживается тенденция повышения скорости передвижения по дистанции. В целом успешное выступление российских биатлонистов на Олимпийских играх было предопределено в основном за счет сочетания точности стрельбы, быстрого передвижения на лыжах и высоких морально-волевых качеств, проявленных в соревнованиях[1]. 
Динамика роста спортивных достижений в современном биатлоне обусловлено прежде всего тремя факторами:

а) высокой точности стрельбы;

б) повышение скорострельности и уменьшением времени пребывания на огневых рубежах;

в)улучшением результатов в чистой гонке и как следствие этого большой плотностью результатов призеров соревнований.

Специфика биатлона - это включение разнохарактерных нагрузок: лыжная гонка и стрельба из мелкокалиберной винтовки в статическом положении на огневых рубежах. Эти два вида мышечной деятельности отличаются друг от друга структурой, характером энергообеспечения, продолжительностью и силой воздействия, что предъявляет к различным системам организма повышенные требования. Динамика роста спортивных достижений в современном биатлоне зависит в первую очередь от следующих факторов: результата в лыжной гонке; повышения скорострельности и уменьшения времени нахождения на огневых рубежах; высокой точности стрельбы. Биатлонист должен уметь правильно делать поправки на ветер, а при порывах ветра приучить себя производить выстрел либо в перерыве между порывами ветра, либо при ветре, добиваясь одинаковых условий для каждого выстрела. Если спортсмен не будет придерживаться этих правил, то у него будет плохая кучность стрельбы, а также большое отклонение средней точки попадания от центра мишени[3].

Вся многолетняя подготовка биатлониста должна рассматриваться как управляемая система, нацелена на достижение наивысших результатов в соответствии с динамикой возрастного развития, индивидуальными особенностями спортсмена и принципами и закономерностями становления спортивного мастерства в биатлоне.

Процесс многолетней подготовки биатлониста весьма сложный и динамичный. Поэтому система управления многолетней подготовкой спортсменов в биатлоне должна быть по возможности простой, легко применяемой в практике.

Построение цикличности обычно начинают с больших циклов, определяя годичную периодизацию тренировки. Периодизация тренировки в биатлоне основывается на общих закономерностях развития тренированности и становление спортивной формы. В связи с сезонностью занятий биатлоном периодизация связана с временами года, календарем соревнований. 
В биатлоне принято следующее построение основного варианта периодизации - год составляет один большой цикл и делится на три периода: подготовительный, соревновательный и переходный.

В зависимости от возраста и подготовленности биатлонистов, количества и напряженности соревнований меняются не только объем и интенсивность применяемых упражнений, но и направленность всего переходного периода. У сильнейших биатлонистов после напряженного и длительного соревновательного периода планируется значительное снижения нагрузки спортсмены должны хорошо отдохнуть. Если у биатлонистов в соревновательном периоде не было большого количества соревнований и они не носили напряженный характер, то переходный период значительно сокращается или даже может быть отменен. Биатлонисты продолжают подготовку, увеличивая нагрузку в подготовительном периоде. В этот период основное внимание обращается на подержание достигнутого уровня ОФП и частично специальной подготовки. Такая периодизация применяется при планировании тренировки различной квалификации. Сроки этапов, их продолжительность не является догмой. Они могут меняться исходя из конкретных внешних условий календаря соревнований и особенностей подготовки спортсмена [1].

Построение тренировочного процесса на основе мезоциклов позволяет систематизировать тренировочный процесс в соответствии с главной задачей периода или этапа подготовки, обеспечить оптимальную динамику нагрузок, целесообразное сочетание различных средств и методов подготовки, соответствие между факторами педагогического воздействия и восстановительными мероприятиями, достичь необходимой преемственности в развитии различных качеств и способностей [3].

1. Астафьев, Н. В. Методика анализа соревновательной деятельности биатлона : учеб.пособие / Н. В. Астафьев, Н. Г. Безмельницын. - Омск : Параграф, 2009. - 122 с.

2. Гельмут, В. Я. Оптимизация тренировочного процесса квалифицированных биатлонистов на основе формирования специальной подготовленности в годичном цикле тренировки :автореф. дис. ... канд. пед. наук / Гельмут Виктор Яковлевич. - СПб, 2000. - 17 с.

3. Степнов, А. И. Особенности тренировочного процесса юных биатлонистов : учеб.пособие / А. И. Степнов. - Омск : Параграф, 2002. - 125 с.

4. Субботин, В. Я. Стрелковая подготовка биатлонистов высших разрядов : учеб.пособие / В. Я. Субботин. - М : Физкультура и спорт, 2004. - 48 с. 